\title{
The Conversionism Theory of Education; Improving Instructional Practice in Higher Education Through Faculty Development and Cross-Institutional Learning Communities
}

\author{
Enoh Nkana \\ Washington Adventist University
}

Enrollment of students with varied learning needs has contributed to a shift in the higher education learning environment. Current teaching and learning strategies are inadequate to meet the needs of these students. The educational theory of conversionism proposes that the developing needs of institutions of higher education can be met by converting the belief system held by stakeholders, especially college instructors, toward the capabilities of students with varying abilities; aligning higher education teaching and learning practices with proven best practices; and bringing awareness of the influence of instructor attitudes on student success. These goals can be met through development of inclusive practices in faculty development and implementation of cross-institutional learning communities.

Keywords: faculty development, higher education, inclusion, intellectual and developmental disabilities

\section{INTRODUCTION}

The climate of the higher education community is shifting. A new generation of students is enrolling in institutions of higher education (IHEs), including students with intellectual and developmental disabilities (IDD) and other learning differences. "Federal legislation is now making it possible for IDD students to enroll in university programs through inclusive postsecondary transition models" (Giust \&Valle-Riestra, 2017, p. 148). Despite an increase in the number of students with IDD in postsecondary education, these students encounter barriers that affect their college experience (Dowrick, Anderson, Heyer, \& Acosta, 2005; Eckes \& Ochoa, 2005; Madaus \& Shaw, 2010; Stodden, Whelley, Chang, \& Harding, 2001). College instructors (CIs) often lack the knowledge, beliefs, and ability to provide accommodations for learning differences without sacrificing academic integrity and rigor (Beilke \& Yssel, 1999; Roa 2004; Sniatecki, Perry, \& Snell, 2015).

Faculty members, staff, and administrators are expected to maintain a high level of expertise within the higher education community (Hendrickson, Vander Busard, Rodgers, \& Acosta, 2013). The most important influencer of academic performance is the support of the professor (Banks, 2014). CIs responsible for teaching courses need to be equipped to meet the diverse needs of this population of learners. To be prepared to teach members of inclusive postsecondary education programs, CIs need to be provided with training and resources on topics including the definitions and characteristics of intellectual and developmental disabilities, the forms of accommodations and modifications, and instructional practices that can be implemented to support the IDD student's successful course completion. 
Education determines well-being, health, and community engagement (Canadian Council on Learning, 2010) and provides individuals with advanced opportunities (Lightfoot, Janemi, \& Rudman, 2018). Upon completion of a postsecondary program, students are more likely to experience financial gains. Vygotsky's sociocultural theory defined the concept of value added from a college education as one's ability to become a contributing member of society. Vygotsky viewed education as an opportunity "to integrate them [students] fully into collective life in ways that contributed to their development of the capabilities that would lead to satisfying lives in cultural context" (Smagorinsky, 2012, p. 13).

The workforce graduates will enter has become more diverse; the world has become more accommodating of people with disabilities or differences. Students are being prepared for a workforce with a shifting climate, one which is looking for creativity and innovation. Innovation is often nurtured through early learning experiences, but all but quashed throughout high school and higher education.

Modernization of the higher education community has focused on how technology can augment the curriculum, more than how improvement of curriculum and instructional strategies can meet the needs of students with varying learning needs. Many two- and four-year IHEs have developed and expanded the breadth of their learning services (Boylan, 1988; Boylan, 1995a), but instructional strategies have rarely been assessed or changed. Updating existing ideas about the ability levels of students with varying abilities through faculty development can align with this shift in the higher education setting and meet the needs of the current student body.

\section{CONVERSIONISM EDUCATIONAL THEORY}

Here I present the theory of educational conversionism as a solution to the newly identified needs of students in a diverse higher education learning environment. According to the Oxford Dictionary (2019), conversionism is characterized by a sudden dramatic experience which brings about a sudden and profound change. The theory of conversionism stems from the practice of converting or conforming to a new system of belief based on CIs implementation of new teaching and learning strategies. These strategies can be taught at faculty development meetings and designed to help CIs meet the needs of students with varying learning abilities. Conversionism is an educational theory focused on three major concepts: a belief in the capabilities of students with varying abilities, alignment of higher education teaching and learning practices with proven best practices, and the influence of instructor attitudes on student success.

The central idea of conversionism theory is the belief that all students possess a degree of ability and potential. The second concept of the conversionism theory is that higher education teaching and learning practices should be aligned more closely with the educational best practices which have been demonstrated to work in the high school and elementary setting; the only major contrast between these levels of education should be the depth and complexity of the content.

Lastly, conversionism proposes that the attitudes and beliefs of instructors regarding students with varying abilities can greatly influence the success of all students, both in the classroom and in the learning community as a whole. Conversionism proposes that the past and present experiences of students with varying levels of learning ability has a powerful influence on an instructor's ability to adapt teaching and learning practices to meet the needs of all learners in the classroom. Thus, instructors who believe all students can be successful will seek to incorporate inclusive instructional practices which will benefit all students.

\section{CURRENT INSTRUCTIONAL PRACTICES}

Professors are experts in their discipline, but usually have had little to no training in instructional practices. Expertise in subject matter is valued more than instructional methodology. A great deal of autonomy is awarded to professors for selection of material and instructional strategies. However, their traditional instructional methods may not benefit the changing demographics of students. This lack of a sense of accountability for the success of students is related to a belief that because students are adults, 
they can be expected to transition from the high school learning format into college without difficulty. Many professors believe students in higher education must conform to traditional teaching and learning strategies such as lectures, even though lectures have been demonstrated to be a less effective forms of instruction.

Today, students have extensive information at their fingertips in the form of smartphones and other digital devices; the professor is no longer the only authority on the topic. Professors tend place an emphasis on the material itself, with little attention given to whether or not the instructional practices are helpful and increase student learning. This is directly the opposite of the emphasis placed on best instructional practices at the elementary and secondary levels. Professors should expand their wealth of knowledge and develop a skill set of instructional strategies which can benefit all students. Professors must be supportive of adapting instruction for students with IDD in their classrooms.

\section{INSTRUCTIONAL NEEDS FOR STUDENTS IN HIGHER EDUCATION}

Students need to be challenged to problem solve and think critically rather than to perform lowerlevel thinking and response patterns. Now that most students have access to technology, teachers should create learning situations in which students are able to research and evaluate relevant and meaningful information on their own. Students can be given some choice in the material they are learning or how they want to demonstrate their learning in a scholarly way. Higher education professors must begin to incorporate these strategies so that students who have been educated using innovative learning methodology will be more successful.

In the realm of education, this encourages institutions to adopt instructional approaches that will benefit the greatest number of students possible. For example, the provision of lecture notes in alternate formats, such as audio recordings, can serve as a strategy for all students to review lecture content at their own pace and in a format consistent with individual learning needs (Lightfoot, et al., p. 60).

\section{FACULTY DEVELOPMENT IN HIGHER EDUCATION}

Mckee \& Tew (2013) define faculty development as "as an intentional set of educational activities designed to equip faculty to grow in their professionalism with the result of being partners in advancing all segments of the institution" (p. 13). Faculty development, when constructed and implemented properly, can elevate higher education competencies. McGuire \& Scott (2006) found that within the postsecondary setting, "there is no unified approach to faculty preparation or ongoing professional development that includes preparation for teaching students with diverse learning needs" (p. 126).

Often, faculty development in higher education introduces new instructional strategies which are completely foreign and beyond the abilities of the professors. Faculty development curricula should take into account the traditional methods which have succeeded while modernizing the teaching and learning framework. Sometimes, faculty development is oriented to content areas, which creates a division rather than a community of learners. Well-designed faculty development programs can refresh the traditional practices of teaching and learning ingrained in the higher education community and can contribute to the success of all students regardless of ability level.

A needs assessment focused on the types of students present and an evaluation of current faculty practices can help guide planning of faculty development programming. Faculty development needs to focus on instructional practices which will best suit the generation of learners present in the current higher education community. Inclusive practices should take into account the influx of students with learning, intellectual, and developmental disabilities. In order to obtain and maintain a greater level of buy-in and implementation, traditional teaching methods can be modernized and enhanced to incorporate inclusive practices. 
College instructors need increased experience, training, and resources about diverse strategies of teaching students with disabilities. For faculty development to be beneficial in equipping professors, who are the most important influencers of student success, to meet the needs of the developing population of IDD students, traditional methods of teaching must be reinforced with inclusive best practices. Faculty members can work collaboratively to improve professional practice.

\section{LEARNING COMMUNITIES}

One method for developing inclusive instruction can be the formation of learning communities. A learning community can promote support across content areas, providing a safe place in which CIs can share ideas, discuss what worked and what didn't work in their classrooms, and make adjustments to teaching strategies. A cohort of professors can be selected to implement inclusive teaching strategies such as assisted note-taking, posting material ahead of time online, cooperative learning, individualized research, project-based learning, and assisting in making the learning relevant and meaningful to the students. These early adopters can then share their expertise with other faculty.

Learning communities across the content of different departments should be nurtured in order to meet the teaching and learning needs of the new and growing population of students with IDD. Traditional methods of instruction can be enhanced with universal design learning and universal design instruction strategies designed for the higher education community. Professors can be encouraged to share their successes and struggles during a designated time in faculty development meetings. Professors must also see the success stories of the capabilities of students with IDD, the benefit they can be to their community if given the proper support. Rather than adding extra time to current faculty meetings, there could be a time designated within meetings for learning communities to meet and be facilitated by members of the education department.

\section{SUMMARY}

Awareness of the needs of students can be brought to the forefront of the mission of the IHE's mission and vision and be reflected in faculty development. Conversionism theory offers higher education an opportunity to meet the needs of all students, incorporating changes in instructor mindsets and skills. All students will benefit as CIs incorporate universally designed instruction and learning strategies to benefit of students with IDD and traditional students. 


\section{REFERENCES}

Banks, J. (2014). Barriers and supports to postsecondary transition: Case studies of African American students with disabilities. Remedial and Special Education, 35, 28-39.

Boylan, H. R. (1995). Making the case for Developmental Education. Research in Developmental Education, 12(2), 1-4

Boylan, H. R. (1988). The historical roots of developmental education: Part III. Review of Research in Developmental Education, 5(3), 1-3

Beilke, J. R., \& Yssel, N. (1999). The chilly climate for students with disabilities in higher education. College Student Journal, 33, 364.

Canadian Council on Learning. (2010). State of learning in Canada: A year in review.

Conversionism. (2019). In Oxford Online Dictionary.

Dowrick, P. W., Anderson, J., Heyer, K., \& Acosta, J. (2005). Postsecondary education across the USA: Experiences of adults with disabilities. Journal of Vocational Rehabilitation, 22, 41-47.

Eckes, S. E., \& Ochoa, T. A. (2005). Students with disabilities: Transitioning from high school to higher education. American Secondary Education, 33(3), 6-20.

Giust, A. M., \& Valle-Riestra, D. M. (2017). Supporting Mentors Working with Students with Intellectual Disabilities in Higher Education. Journal of Intellectual Disabilities, 21(2), 144-157.

Hendrickson, J. M., Vander Busard, A., Rodgers, D., \& Scheidecker, B. (2013). College Students with Intellectual Disabilities: How Are They Faring? Journal of College and University Student Housing, 40(1), 186-199.

Lightfoot, A., Janemi, R., \& Rudman, D. L. (2018). Perspectives of North American Postsecondary Students with Learning Disabilities: A Scoping Review. Journal of Postsecondary Education and Disability, 31(1), 57-74.

McKee, C. W., \& Tew, W. M. (2013). Setting the Stage for Teaching and Learning in American Higher Education: Making the Case for Faculty Development. New Directions for Teaching and Learning, 133, 3-14.

McGuire, J. M., \& Scott, S. S. (2006). Universal Design for Instruction: Extending the Universal Design Paradigm to College Instruction. Journal of Postsecondary Education and Disability, 19(2), 124 134.

Rao, S. (2004). Faculty attitudes and students with disabilities in higher education: A literature review. College Student Journal, 38, 191-198.

Shaw, S. F., Madaus, J. W., \& Dukes, L. L., III. (2010). Preparing Students with Disabilities for College Success: A Practical Guide to Transition Planning. Brookes Publishing Company.

Smagorinsky, P. (2012). Vygotsky, "Defectology," and the Inclusion of People of Difference in the Broader Cultural Stream. Journal of Language and Literacy Education [Online], 8(1), 1-25.

Sniatecki, J. L., Perry, H. B., \& Snell, L. H. (2015). Faculty Attitudes and Knowledge Regarding College Students with Disabilities. Journal of Postsecondary Education and Disability, 28(3), 259-275.

Stodden, R. A., Whelley, T., Chang, C., \& Harding, T. (2001). Current status of educational support to students with disabilities in postsecondary education. Journal of Vocational Rehabilitation, 16, 189-19. 